\title{
Optimizing speleological monitoring efforts: Insights from long-term data for tropical iron caves
}

\author{
Leonardo Trevelin $^{1}$, Matheus Simões ${ }^{2}$, Xavier Prous ${ }^{2}$, Thadeu Pietrobon ${ }^{2}$, Iuri Viana Brandi ${ }^{2}$, Rodolfo Jaffé ${ }^{\text {Corresp. } 1}$ \\ ${ }^{1}$ Biodiversity and Ecosystem Services, Instituto Tecnológico Vale, Belém, Pará, Brazil \\ 2 Environmental Licensing and Speleology, Vale S.A., Nova Lima, Minas Gerais, Brazil \\ Corresponding Author: Rodolfo Jaffé \\ Email address: r.jaffe@ib.usp.br
}

Understanding the factors underpinning species abundance patterns in space and time is essential to implement effective cave conservation actions. Yet, the methods employed to monitor cave biodiversity still lack standardization, and no quantitative assessment has yet tried to optimize the amount and type of information required to efficiently identify disturbances in cave ecosystems. Using a comprehensive monitoring dataset for tropical iron caves, comprising abundance measurements for 33 target taxa surveyed across 95 caves along four years, here we provide first evidence-based recommendations to optimize monitoring programs seeking to follow target species abundance through time. We found that seasonality did not influence the ability to detect temporal abundance trends. However, in most species, abundance estimates assessed during the dry season resulted in a more accurate detection of temporal abundance trends, and at least three surveys were required to identify global temporal abundance trends. Finally, we identified a subset of species that could potentially serve as short-term disturbance indicators. Results suggest that iron cave monitoring programs implemented in our study region could focus sampling efforts in the dry season, where detectability of target species is higher, while assuring data collection for at least three years. More generally, our study reveals the importance of long-term cave monitoring programs for detecting possible disturbances in subterranean ecosystems, and for using the generated information to optimize future monitoring efforts. 
1 Optimizing speleological monitoring efforts: Insights 2 from long-term data for tropical iron caves

3

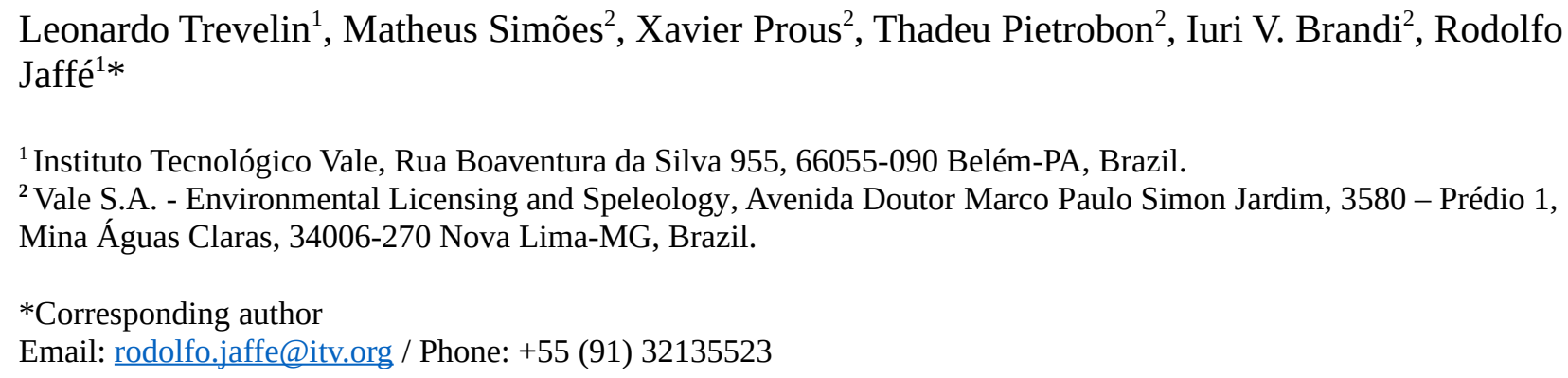

\begin{abstract}
Understanding the factors underpinning species abundance patterns in space and time is essential to implement effective cave conservation actions. Yet, the methods employed to monitor cave biodiversity still lack standardization, and no quantitative assessment has yet tried to optimize the amount and type of information required to efficiently identify disturbances in cave ecosystems. Using a comprehensive monitoring dataset for tropical iron caves, comprising abundance measurements for 33 target taxa surveyed across 95 caves along four years, here we provide first evidence-based recommendations to optimize monitoring programs seeking to follow target species abundance through time. We found that seasonality did not influence the ability to detect temporal abundance trends. However, in most species, abundance estimates assessed during the dry season resulted in a more accurate detection of temporal abundance trends, and at least three surveys were required to identify global temporal abundance trends. Finally, we identified a subset of species that could potentially serve as short-term disturbance indicators. Results suggest that iron cave monitoring programs implemented in our study region could focus sampling efforts in the dry season, where detectability of target species is higher, while assuring data collection for at least three years. More generally, our study reveals the importance of long-term cave monitoring programs for detecting possible disturbances in subterranean ecosystems, and for using the generated information to optimize future monitoring efforts.
\end{abstract}

\title{
Keywords
}

Iron caves, landscape ecology, mining, speleology, subterranean communities, troglobiont. 


\section{Introduction}

Quantifying long-term changes in abundance of cave-dwelling organisms and identifying indicator species, reflecting the health status of subterranean ecosystems, are among the fundamental research goals of modern subterranean conservation biology (Mammola et al., 2020). For instance, the lack of knowledge about the factors underpinning abundance patterns in space and time are among the main impediments to the effective protection of cave fauna (Cardoso et al., 2011). Long-term studies in caves are scarce (Di Russo et al., 1997; Salvidio et al., 2019), and most previous efforts assessing community-level responses have evaluated population dynamics (Bichuette \& Trajano, 2003; Ferreira et al., 2005; Lunghi, 2018), ecological niches (Mammola \& Isaia, 2016; Mammola, Piano \& Isaia, 2016), or temporal and spatial variation (Tobin, Hutchins \& Schwartz, 2013; Ferreira et al., 2015; Owen et al., 2016; Paixão, Emanuelle Arantes Ferreira \& Paixão, 2017; Mammola \& Isaia, 2018; Ferreira \& Pellegrini, 2019; Pellegrini, Faria \& Ferreira, 2020). Few studies have evaluated the influence of anthropogenic disturbance on cave biodiversity (Bernardi, Souza-Silva \& Ferreira, 2010; Pellegrini \& Lopes Ferreira, 2012; Faille, Bourdeau \& Deharveng, 2015; Cajaiba, Cabral \& Santos, 2016; Pellegrini et al., 2016; Jaffé et al., 2018).

Due to the unique characteristics of subterranean environments, an important fraction of cave fauna exhibits adaptations for life in these extreme environments (Pipan \& Culver, 2013). Some of these species are obligate subterranean dwellers and often comprise narrow-range endemic and threatened species (Harvey, 2002), so stringent legislation has been put in place in some countries to protect them (Harvey et al., 2011; Culver \& Pipan, 2014). In Brazil, companies executing projects that could potentially impact cave ecosystems are required by law to assess the extent of impacts and implement control, monitoring and/or compensation measures (CONAMA, 1986; Decree, 2008; MMA/ICMBio, 2019). After environmental licenses are granted, some caves are included in long-term monitoring programs, ultimately seeking to detect possible disturbances on subterranean fauna. These studies generate comprehensive biological databases containing valuable information for numerous caves sampled over long periods of time (Jaffé et al., 2016, 2018; Trevelin et al., 2019). However, although many recommendations have been made to monitor cave biodiversity (Eberhard, 2001; NPS, 2015; Culver \& Sket, 2016), methods still lack standardization, and no quantitative assessment has yet tried to optimize the amount and type of information required to efficiently identify disturbances in cave ecosystems. This is nevertheless essential to design systematic, repeatable, and intensive surveys of cave-dwelling organisms, allowing the formulation of evidence-based management decisions (Wynne et al., 2018, 2019).

In Brazil, most cave monitoring programs have focused on assessing temporal changes in relative abundance in a set of selected species (ativoambiental, 2019; BRANDT, 2019). However, the temporal frequency of field surveys, the impact of seasonal fluctuations in population size, and the sample sizes needed to detect temporal changes in population abundance, are yet to be systematically assessed. Moreover, the selection of species surveyed in these monitoring programs is not based on their usefulness as disturbance bio-indicators. Here we aim to fill these gaps, taking advantage of a comprehensive cave monitoring dataset containing abundance measurements for target target taxa surveyed across iron caves along four years.

\section{Material \& Methods}

\section{Study Area}

The study was performed in the Serra dos Carajás region, southeast of the state of Pará, in the Brazilian Amazon. This region is within the limits of the Floresta Nacional de Carajás, a 
87 protected area of 400,000 ha allowing sustainable use. The caves analyzed in this study are

88 located in two highlands known as Serra Norte and Serra Sul (Fig. 1). These two regions harbor

89 banded ironstone formations known as cangas, unique campo rupestre ecosystems resembling

90 mountain savannas (Zappi et al., 2019), and one of the world's largest deposits of iron ore

91 (Poveromo, 1999).

92

93

\section{Database}

We used data generated by independent environmental consulting companies, so our study did not involve any field work. Vale S.A., a mining company, began operations in the region more than two decades ago (Souza-Filho et al., 2019), and has conducted numerous caves surveys over the last years as part of a large monitoring program related to environmental licensing processes. All surveys where authorized by Instituto Brasileiro do Meio Ambiente e dos Recursos Naturais Renováveis (IBAMA), under licenses ABIO 455/2014 (Projeto Ferra Carajás S11D no 02001.000711/2009-46) and ABIO 639/2015 (Projeto Ferro Serra Norte - Estudo Global das Ampliações das minas N4 e N5 n 02001.002197/2002-15). We compiled the data generated in these surveys to collect information from 33 target taxa across 95 caves, surveyed between August 2015 and September 2019. The selection of species included in these monitoring programs was based on the following criteria, as stated in environmental assessment reports (Vale, 2015, 2017): Large body size and easy to identify in the field, abundant and showing a wide distribution range, resolved taxonomic classification (at least to the morpho-species level), and short life cycles allowing the rapid detection of changes in population dynamics (see Table 1 for the full list of target taxa and their ecological classification). All the selected species were actively surveyed during each field trip, so absences represent true absences rather than missing data. In each cave, the absolute abundance of each target taxa was quantified at least once during the rainy and the dry season, and sometimes multiple times in one year. Sampling was performed through an active visual search throughout the caves, aiming to cover all available micro-habitats (spaces under rocks, small cracks, moist soil, etc.) and organic deposits (litter, logs, carcasses, guano, etc.). Animals were collected with the aid of tweezers and brushes, and all individuals found in each cave were counted to estimate abundance per species, as performed in other studies (Silva, Martins \& Ferreira, 2011; Ferreira et al., 2015; Bento et al., 2016; Pellegrini \& Ferreira, 2016; Paixão, Emanuelle Arantes Ferreira \& Paixão, 2017; Ferreira \& Pellegrini, 2019; SouzaSilva, Iniesta \& Ferreira, 2020).

\section{Environmental conditions and landscape metrics}

External and internal environmental conditions were monitored during the entire period across caves. Monitored variables included the deviation in average bimonthly rainfall in relation to the expected from a 20-years series (in $\mathrm{mm}$, retrieved from small weather stations located in nearby mines S11D e N4E), and mean internal temperature $\left({ }^{\circ} \mathrm{C}\right)$ on the date of the surveys (retrieved from portable data loggers placed in the most distant location from cave entrances). We also recorded the Area (meters ${ }^{2}$ ) of each studied cave as an additional internal condition widely known to influence biodiversity patterns in these ecosystems (Jaffé et al., 2016, 2018). Using 30m resolution land-cover maps from 2015 to 2019 (Souza et al., 2020), we then quantified a suit of landscape metrics, including the proportional amount of forest, canga and mining land covers surrounding caves, and topographic distance to the nearest mine (see details in Supplemental Table S1). These were all calculated at two different spatial scales (circular buffers with 500 and 1000 m radius), using the R packages landscapemetrics (Hesselbarth et al., 2019) and TopoDistance (Wang, 2020). Two of these metrics directly captured possible disturbance of subterranean environments that could account for changes in the abundance of the studied species: Mining cover and distance to the nearest mine. 
136

137

138

139

140

141

142

143

144

145

146

147

148

149

150

151

152

153

154

155

156

157

158

159

160

161

162

163

164

165

166

167

168

169

170

171

172

173

174

175

176

177

178

179

180

181

182

183

184

Assessing drivers of community composition across caves

Aiming to quantify how environment, cave, and landscape variables influenced overall community composition, we ran a partial redundancy analysis (RDA) controlling for differences between both highlands (Serra Norte and Serra Sul), using the vegan package (Oksanen et al., 2019). The community composition matrix containing relative abundances for each taxa was used as response variable and predictor variables included year, season, microclimate and landscape metrics (Legendre \& Legendre, 1998). The highland where caves were located was specified as a conditional variable on the model to control for the effect of cave's geographical location.

Microclimate and landscape variables were standardized, community composition was Hellingertransformed, and permutation tests were used to assess significance of marginal effects (Legendre \& Legendre, 1998).

Assessing the influence of seasonality on the detection of temporal abundance trends One of the main goals of cave monitoring programs was to assess changes in species abundance over time, and thereby identify species with declining or increasing populations in a particular cave. To understand how seasonality influenced the detection of abundance trends over time, we ran linear models containing the total number of observed individuals as the response variable and the interaction between sampling date and season. If seasonality influences temporal abundance trends, we would expect to find significant interaction terms. No significant interactions, on the other hand, would indicate that the trends can be detected regardless of the season when the surveys where performed. To prevent overfitting, linear models were ran for taxa and caves represented by at least five surveys in each season (final sample size was 16 taxa and 50 caves). Given the large number of models we used the Benjamini \& Hochberg approach to adjust $p$-values, employing the p.adjust function from the stats R package (R, 2020).

\section{Assessing the influence of sampling effort on the detection of temporal abundance trends} Given the extensive field exposure of people and elevated costs associated with cave monitoring programs, it is important to quantify how the sampling effort influences the detection of temporal abundance trends. To do so we compared linear model coefficients of models fitted with the full dataset with those of models fitted with reduced datasets. We first split the data by season and ran linear models containing the total number of observed individuals as the response variable and sampling date as predictor. In these full models we included observations for all sampling dates, and excluded taxa and caves represented by less than three surveys per season. We then ran linear models on data subsets containing a reduced number of observations (ranging between two and the maximum number of sampling dates found in each cave and taxa). For each data subset containing a given number of observations (surveys) we performed ten random samplings without replacement, to ensure the sampling of different sampling dates. Finally, we compared coefficients from full models with those of subset models using root mean squared error (rmse), implemented through the rmse function from the Metrics R package (Hamner \& Frasco, 2018). Lower values of rmse indicate more similar model coefficients.

\section{Identifying disturbance indicator species}

Given the life history variation between species and their different susceptibility to habitat disturbance, it is essential to identify indicator species that show a rapid response to disturbance in order to optimize monitoring programs. By focusing on these indicator species, monitoring programs could survey caves more efficiently, thereby making resources available to study more caves or other aspects of cave biodiversity requiring attention. Here we tried to identify disturbance indicator species by assessing the relationship between disturbance metrics and

PeerJ reviewing PDF | (2020:12:56752:1:0:NEW 12 Feb 2021) 
185 species abundance patterns. We first modeled patterns of relative abundance across all caves,

186 using the function manyglm from the R package mvabund (Wang et al., 2012). It uses a

187 multivariate generalized linear model (GLM) to make inferences by fitting separate GLMs to a

188 common set of explanatory variables, and testing significance through resampling-based

189 hypothesis testing. We ran negative binomial GLMs containing abundance as the response

190 variable and sampling season nested in year, distance to mine and mining cover as predictor

191 variables. Significance $p$-values were calculated using 999 resampling iterations via PIT trap

192 resampling, adjusted for multiple testing using a step-down resampling procedure (Wang et al.,

193 2012). We then used univariate coefficient estimates and significance for individual species, to

194 identify specific responses to disturbance metrics (distance to mine and mining cover).

195 We then assessed the relationship between disturbance metrics and temporal trends in

196 species abundance within each cave. To do so we ran linear models containing the total number

197 of observed individuals as the response variable and sampling date as predictor, excluding taxa

198 and caves represented by surveys spanning less than three years (some caves where surveyed

199 multiple times in a single year but these where only included in this analysis if surveys spanned at

200 least three different years). We then used the model coefficients for each species at each cave,

201 representing temporal abundance trends (positive coefficients showing an increase and negative

202 coefficients a decrease in abundance through time), to run a second set of linear models

203 regressing temporal abundance trends on disturbance metrics. These second set of models thus

204 contained as response variable the model coefficients representing temporal abundance trends for

205 each species at each cave, and distance to mine and mining cover (at different spatial and

206 temporal scales) as predictors. To prevent overfitting we excluded species represented by less

207 than ten coefficients (caves), and only constructed models containing a single predictor. We then

208 ran likelihood-ratio tests, where we compared each model with a null model containing no

209 predictors, and selected those predictor variables resulting in a significant decrease in the model's

210 log-likelihood. Finally, we retrieved and plotted coefficients and $p$-values for these best-fitting

211 models. All data and R scripts are available in GitHub

212 (https://github.com/rojaff/cave monitoring).

213

214

215

216 Overall community composition was weakly influenced by seasonality, cave size, environmental

217 conditions, and the composition and configuration of landscapes surrounding caves, as more than

218 87\% of variance in community composition remained unexplained by these factors (Table 2).

219

220

Seasonality did not influence the ability to detect species abundance trends over time, since

221 (Fig. 2). Increasing the number of samples resulted in more similar model coefficients between

222

223

224

225

226

227

228

229

230 full and subset models, and root mean squared errors usually stabilized after three surveys (Fig. 3). However, in most species the dry season datasets allowed a more accurate detection of temporal abundance trends, as revealed by lower root mean squared errors (Fig. 3).

Whereas relative abundance was associated to at least one disturbance metric in 22 species (Fig. 4), temporal trends in abundance were found associated with disturbance metrics in only five species (Fig. 5). Overall, two taxa displayed consistent responses across effects, which makes them potential indicator species for cave monitoring programs: The troglobiont Charinus ferreus, which appeared negatively affected by disturbance, and a species belonging the 


\section{Discussion}

233

234

235

236

237

238

239

240

241

242

243

244

245

246

247

248

249

250

251

252

253

254

255

256

257

258

259

260

261

262

263

264

265

266

267

268

269

270

271

272

273

274

275

276

277

278

279

280
By analyzing abundance measurements for 33 target taxa surveyed across 95 caves along four years, we found that overall community composition was weakly influenced by seasonality, cave size, environmental conditions, and the composition and configuration of landscapes surrounding caves. Furthermore, our results show that seasonality did not influence the ability to detect abundance trends over time. However, in most species, abundance estimates assessed during the dry season resulted in a more accurate detection of temporal abundance trends, and at least three surveys were required to identify global temporal abundance trends. Finally, we identified a subset of species that could potentially serve as short-term disturbance indicators, some showing consistent responses in different analyses.

Subterranean communities have been shown to be affected by seasonality, environmental conditions, cave characteristics, and the structure of surrounding landscapes (Simões, SouzaSilva \& Ferreira, 2015; Pellegrini et al., 2016; Bento et al., 2016; Mammola \& Isaia, 2018; Salvidio et al., 2019; Pellegrini, Faria \& Ferreira, 2020; Rabelo, Souza-Silva \& Ferreira, 2020). However, our results reveal that overall community composition was only weakly influenced by these factors, as our model explained merely $13 \%$ of total variation in community composition (Table 2). In contrast, previous work have found that cave morphology, microclimate, cave depth, and sampling date explain up to $50 \%$ of the variation in community structure in limestone and marble caves (Tobin, Hutchins \& Schwartz, 2013; Lunghi, Manenti \& Ficetola, 2014). Our results thus suggest that other factors, not considered in our analyses, play an important role structuring subterranean communities of iron caves. Inter-specific interactions, for instance, are known to have a profound influences on community structure (Ferreira \& Martins, 1999; Mammola, Piano \& Isaia, 2016). Alternatively, biological samples collected in iron caves may not capture the dynamics of the entire subterranean habitat, comprised by a network of fissures and voids and traditionally referred to as Milieu Souterrain Superficiel (MSS) (Culver \& Pipan, 2014; Mammola et al., 2016; Mammola, 2018). For instance, most of the surveyed caves were larger than 5x5 m (Fig. S1), so they did not represent suitable sampling sites for the MSS (Mammola et al., 2016).

Even though seasonality affected overall community composition, it did not influence the ability to detect species abundance trends over time. External climatic conditions are increasingly attenuated at higher cave depths (Tobin, Hutchins \& Schwartz, 2013), so species occurring in the inner portions of caves appear to have life cycles decoupled from external seasons, whereas species inhabiting the outermost portions of caves seem to be more strongly affected by seasonality (Di Russo et al., 1997; Gunn, Hardwick \& Wood, 2000; Bichuette \& Trajano, 2003; Ferreira et al., 2015; Mammola, Piano \& Isaia, 2016; Lunghi, 2018). Recognizing the impact of seasonality on species detection, the current Brazilian legislation stipulates that cave biodiversity surveys need to comprise at least two sampling events, one during the dry and one during the rainy season (MMA, 2017). It is worth emphasizing that these sampling requirements targeted a more accurate estimation of species richness, but not the continuous monitoring of focus species in time. Two sampling events are likely insufficient to obtain reliable species richness estimates for highly diverse caves (Auler \& Piló, 2015; Wynne et al., 2018), so some authors have argued for the estimation of optimal sample sizes based on species accumulation curves (Trajano \& Bichuette, 2010; Trajano, 2013). Our results provide the first evidence-based recommendations to optimize sampling efforts of monitoring programs seeking to assess target species abundance through time. Specifically, our findings suggest that monitoring efforts aiming to detect changes in abundance through time do not need to sample during two different seasons each year (Fig. 2). Sampling efforts of such monitoring programs could thus be optimized by performing more focused surveys and by surveying a larger number of caves during the same period each year. 
281 Importantly, restricting sampling to a single season could substantially attenuate the negative 282 impact of cave visitation by researchers on subterranean communities (Pellegrini \& Ferreira

283

284

285

286

287

288

289

290

291

292

293

294

295

296

297

298

299

300

301

302

303

304

305

306

307

308

309

310

311

312

313

314

315

316

317

318

319

320

321

322

323

324

325

326

327

328

329
2016, Pellegrini \& Lopes Ferreira 2012, Bernardi et al. 2010).

Although the composition and spatial distribution of subterranean communities can remain constant over periods of several years (Salvidio et al., 2019), our results suggest that sampling during at least three years is necessary to detect temporal changes in abundance patterns in most of our focus species (Fig. 3). We note that our dataset only spans a period of four years (although some caves were sampled multiple times during the same season/year), so it cannot capture longer temporal changes in abundance. We also caution that these results cannot be generalized to all subterranean fauna, as different life histories and generation times will ultimately determine how fast these organisms respond to disturbances (Ferreira, 2005; Mammola et al., 2016; Culver \& Pipan, 2019). Sampling in different seasons did not influence the ability to detect general abundance trends over time, but the dry season datasets allowed a more accurate detection of temporal abundance trends in most species. These results suggest higher detection probabilities in the dry season for the subset of species where RMSE curves show a steeper decrease during the dry season (Fig. 3). Interestingly, this was the case for the troglobitic amblypygid Charinus ferreus, a species that is difficult to detect like other troglobionts (Wynne et al., 2018; Lunghi, 2018). Our results thus suggest that monitoring programs focusing on terrestrial subterranean fauna from our study region could concentrate sampling activity in the dry season, where most species seem to be easier to detect. Likewise, our findings highlight the importance of implementing long-term monitoring efforts spanning at least three years.

The concept of indicator species in ecosystem management relies on the idea of identifying taxa responsive to environmental change, that could inform policies, protocols, and best practices (Carignan \& Villard, 2002). Such environmental indicators (McGeoch, 1998) seek to provide cost and time effective guidelines to address pressing conservation issues, such as those faced by large-scale mining projects (Sonter, Ali \& Watson, 2018). Assessing the response of subterranean fauna to anthropogenic disturbance nevertheless requires access to long-term cave monitoring datasets, which are remarkably rare for tropical caves (McGeoch, 1998; Carignan \& Villard, 2002; Mammola et al., 2020). Here we identified 20 taxa where overall abundance responded to cave disturbance, and five where temporal abundance trends where associated with disturbance. Only two taxa displayed consistent responses across effects, which makes them candidate indicator species for cave monitoring programs: Charinus ferreus and a species belonging the Theraphosidae family (Table2). Both are arachnids, a group that was recently identified as biodiversity indicator for iron caves (Trevelin et al., 2019). Being a top predator restricted to cave ecosystems, the first species is a well-known troglobitic Amblypygi (Giupponi \& de Miranda, 2016). Its strong and consistent response to disturbances (Figs. 4 and 5) suggest the species is associated with pristine and undisturbed ecosystems, which makes it an ideal disturbance indicator. Theraphosidae spiders, on the other hand, are sedentary sit-and-wait predators from the epigea, rarely occupying subterranean environments for reproduction or shelter (Fonseca-Ferreira, Zampaulo \& Guadanucci, 2017). Our results suggest that they apparently benefit from disturbance to opportunistically colonize caves, or alternatively, that disturbances in the surrounding external habitats are forcing them to look for shelter inside the caves. The species nevertheless awaits formal taxonomic description, which currently limits its usefulness as an indicator species.

Effect sizes of disturbance on overall abundance and temporal abundance trends where generally small, suggesting that some effects could have remained undetected because they would require sampling over longer time periods (Di Stefano, 2001; Legg \& Nagy, 2006). For instance, the ability to detect trends in tropical bat population abundance was shown to be 
330 dependent on the duration of the monitoring efforts, and only long programs ( $>20$ years) showed

331 sufficient statistical power to reliably detect abundance trends (Meyer et al., 2010). This could

332 explain why some of our focus species did not exhibit coherent responses across analyses, like

333 the troglobionts Pyrgodesmidae sp. and Escadabiidae sp., or opportunistic colonizers like the

334 anuran Leptodactylus pentadactylus or Pristimantis fenestratus. Although empirical evidence

335 from long-term cave monitoring efforts focusing on invertebrates is scarce (Faille, Bourdeau \&

336 Deharveng, 2015; Cajaiba, Cabral \& Santos, 2016; Owen et al., 2016), our results thus suggest

337 that longer monitoring efforts are needed to detect disturbance responses in most cave-dwelling

338 species.

339

340

341

342

343

344

345

346

347

348

349

350

351

352

353

\section{Conclusions}

Our study reveals the importance of long-term cave monitoring programs for detecting possible disturbances in subterranean ecosystems, and for using the generated information to optimize future monitoring efforts. Results show that iron cave monitoring programs implemented in our study region could focus sampling efforts in the dry season, where detectability of target species is higher, while assuring data collection for at least three years. Charinus ferreus was identified as the most promising short-term disturbance indicator species.

\section{Acknowledgments}

We thank Ativo Ambiental and Brandt Meio Ambiente for performing the speleological surveys that generated all the data used in this study, and David Culver and Judson Wynne for helping us improve our manuscript with their constructive criticism. 
354

355

356

357

358

359

360

361

362

363

364

365

366

367

368

369

370

371

372

373

374

375

376

377

378

379

380

381

382

383

384

385

386

387

388

\section{References}

ativoambiental. 2019. Plano Básico Ambiental Projeto Ferro Carajás S11D - Monitoramento Biológico e Climático.

Auler AS, Piló LB. 2015. Caves and mining in Brazil: The dilemma of cave preservation within a mining context. In: Andreo B, Carrasco F, Durán JJ, Jiménez P, LaMoreaux JW eds. Environmental Earth Sciences. Environmental Earth Sciences. Berlin, Germany: Springer Berlin Heidelberg, 487-496. DOI: 10.1007/978-3-642-17435-3_55.

Bento D de M, Ferreira R, Prous X, Souza-Silva M, Bellini BC, Vasconcellos A. 2016. Seasonal variations in cave invertebrate communities in the semiarid Caatinga, Brazil. Journal of Cave and Karst Studies 78:61-71. DOI: 10.4311/2015LSC0111.

Bernardi LFO, Souza-Silva M, Ferreira RL. 2010. Considerações sobre os efeitos do turismo no ecossistema da Mina do Chico Rei (Ouro Preto, Minas Gerais): Implicações para o manejo em sistemas naturais. Turismo e Paisagens Cársticas 3.

Bichuette ME, Trajano E. 2003. A population study of epigean and subterranean Potamolithus snails from southeast Brazil (Mollusca: Gastropoda: Hydrobiidae). Hydrobiologia 505:107117. DOI: 10.1023/B:HYDR.0000007299.26220.b8.

BRANDT. 2019. Monitoramento da Fauna e Condições Ambientais em Cavidades.

Cajaiba RL, Cabral JA, Santos M. 2016. A Minimal Invasive Method to Forecast the Effects of Anthropogenic Disturbance on Tropical Cave Beetle Communities. Neotropical Entomology 45:139-147. DOI: 10.1007/s13744-015-0349-7.

Cardoso P, Erwin TL, Borges PAV, New TR. 2011. The seven impediments in invertebrate conservation and how to overcome them. Biological Conservation. DOI: 10.1016/j.biocon.2011.07.024.

Carignan V, Villard M-A. 2002. Selecting Indicator Species to Monitor Ecological Integrity: A Review. Environmental Monitoring and Assessment 78:45-61. DOI: 10.1023/A:1016136723584.

CONAMA. 1986. RESOLUÇÃO CONAMA n ${ }^{\circ}$ 1, de 23 de janeiro de 1986. Brazil: Diário Oficial da União.

Culver DC, Pipan T. 2014. Shallow subterranean habitats: ecology, evolution, and conservation. New York, US: Oxford University Press, USA.

Culver DC, Pipan T. 2019. The Biology of Caves and Other Subterranean Habitats. Oxford University Press. DOI: 10.1093/oso/9780198820765.001.0001.

Culver DC, Sket B. 2016. Biological Monitoring in Caves. Acta Carsologica 31:55-64. DOI: 10.3986/ac.v31i1.403. 
389

390

391

392

393

394

395

396

397

398

399

400

401

402

403

404

405

406

407

408

409

410

411

412

413

414

415

416

417

418

419

420

421

422

Decree. 2008. DECRETO N 6.640, DE 7 DE NOVEMBRO DE 2008. Brazil: Presidência da República - Casa Civil.

Eberhard S. 2001. Cave fauna monitoring and management at Ida Bay, Tasmania. DOI: 10.18195/issn.0313-122x.64.2001.097-104.

Faille A, Bourdeau C, Deharveng L. 2015. Weak impact of tourism activities on biodiversity in a subterranean hotspot of endemism and its implications for the conservation of cave fauna. Insect Conservation and Diversity 8:205-215. DOI: 10.1111/icad.12097.

Ferreira RL. 2005. A vida subterrânea nos campos ferruginosos. O carste 3:106-115.

Ferreira RL, Martins RP. 1999. Trophic structure and natural history of bat guano invertebrate communities, with special reference to Brazilian caves. Tropical zoology 12:231-252.

Ferreira RL, Martins VM, Emanuelle Arantes Paixão, Silva MS. 2015. Spatial and temporal fluctuations of the abundance of neotropical cave-dwelling moth Hypena sp. (Noctuidae, Lepidoptera) influenced by temperature and humidity. Subterranean Biology. DOI: 10.3897/ subtbiol.16.5137.

Ferreira R, Pellegrini T. 2019. Species-area model predicting diversity loss in an artificially flooded cave in Brazil. International Journal of Speleology 48:155-165. DOI: 10.5038/1827-806X.48.2.2244.

Ferreira RL, Prous X, Machado SF, Martins RP. 2005. Population dynamics of Loxosceles similis (Moenkhaus, 1898) in a brazilian dry cave: a new method for evaluation of population size. Revista Brasileira de Zoociências.

Fonseca-Ferreira R, Zampaulo R de A, Guadanucci JPL. 2017. Diversity of iron cave-dwelling mygalomorph spiders from Pará, Brazil, with description of three new species (Araneae). Tropical Zoology 30:178-199. DOI: 10.1080/03946975.2017.1367590.

Giupponi AP de L, de Miranda GS. 2016. Eight New Species of Charinus Simon, 1892 (Arachnida: Amblypygi: Charinidae) Endemic for the Brazilian Amazon, with Notes on Their Conservational Status. PLOS ONE 11:e0148277. DOI: 10.1371/journal.pone.0148277.

Gunn J, Hardwick P, Wood PJ. 2000. The invertebrate community of the Peak-Speedwell cave system, Derbyshire, England — pressures and considerations for conservation management. Aquatic Conservation: Marine and Freshwater Ecosystems 10:353-369. DOI: 10.1002/1099-0755(200009/10)10:5<353::AID-AQC413>3.0.CO;2-S.

Hamner B, Frasco M. 2018. Metrics: Evaluation Metrics for Machine Learning.

Harvey MS. 2002. Short-range endemism amongst the Australian fauna: some examples from non-marine environments. Invertebrate Systematics 16:555-570. DOI: https://doi.org/10.1071/IS02009. 
Harvey MS, Rix MG, Framenau VW, Hamilton ZR, Johnson MS, Teale RJ, Humphreys G, Humphreys WF. 2011. Protecting the innocent: studying short-range endemic taxa enhances conservation outcomes. Invertebrate Systematics 25:1. DOI: 10.1071/IS11011.

Hesselbarth MHK, Sciaini M, With KA, Wiegand K, Nowosad J. 2019. landscapemetrics 
459

460

461

462

463

464

465

466

467

468

469

470

471

472

473

474

475

476

477

478

479

480

481

482

483

484

485

486

487

488

489

490

491

492

493

494

Mammola S, Isaia M. 2018. Day-night and seasonal variations of a subterranean invertebrate community in the twilight zone. Subterranean Biology. DOI: 10.3897/SUBTBIOL.27.28909.

Mammola S, Piano E, Isaia M. 2016. Step back! Niche dynamics in cave-dwelling predators. Acta Oecologica 75:35-42. DOI: 10.1016/j.actao.2016.06.011.

McGeoch MA. 1998. The selection, testing and application of terrestrial insects as bioindicators. Biological Reviews of the Cambridge Philosophical Society 73:S000632319700515X. DOI: 10.1017/S000632319700515X.

Meyer CFJ, Aguiar LMS, Aguirre LF, Baumgarten J, Clarke FM, Cosson J-F, Villegas SE, Fahr J, Faria D, Furey N, Henry M, Hodgkison R, Jenkins RKB, Jung KG, Kingston T, Kunz TH, MacSwiney Gonzalez MC, Moya I, Pons J-M, Racey PA, Rex K, Sampaio EM, Stoner KE, Voigt CC, Staden D von, Weise CD, Kalko EKV. 2010. Long-term monitoring of tropical bats for anthropogenic impact assessment: Gauging the statistical power to detect population change. Biological Conservation 143:2797-2807. DOI: 10.1016/j.biocon.2010.07.029.

MMA/ICMBio. 2019. INSTRUÇÃO NORMATIVA CONJUNTA No 8, DE 27 DE SETEMBRO DE 2019. Diario Oficial da União.

MMA. 2017. INSTRUÇÃO NORMATIVA N ${ }^{\circ}$ 2, DE 30 DE AGOSTO DE 2017. Brazil: Diario Oficial da União.

NPS. 2015. A Protocol for Monitoring Cave Crickets ( Hadenoecus subterraneus ) at Mammoth Cave National Park.

Oksanen J, Blanchet FG, Friendly M, Kindt R, Legendre P, McGlinn D, Minchin PR, O’Hara RB, Simpson GL, Solymos P, Stevens MHH, Szoecs E, Wagner H. 2019. vegan: Community Ecology Package.

Owen JD, van Kampen-Lewis S, White K, Crawford C. 2016. Preliminary study of central Texas cave cricket monitoring (Orthoptera: Rhaphidophoridae). The Southwestern Naturalist 61:265-269. DOI: 10.1894/0038-4909-61.3.265.

Paixão, Emanuelle Arantes Ferreira RL, Paixão CA. 2017. Spatial distribution and seasonal behavior of Endecous aguassay and Eidmanacris lencionii (Orthoptera: Grylloidea, Phalangopsidae) in an artificial iron ore cave. Speleobiology Notes 9. DOI: 10.5563/spbn.v9i0.85.

Pellegrini TG, Faria LDB, Ferreira RL. 2020. Temporal diversity patterns of benthic insects in subterranean streams: a case study in Brazilian quartzite caves. Hydrobiologia. DOI: 10.1007/s10750-020-04262-6.

Pellegrini TG, Ferreira RL. 2016. Are inner cave communities more stable than entrance communities in Lapa Nova show cave? Subterranean Biology 20:15-37. DOI: 10.3897/subtbiol.20.9334. 
495

496

497

498

499

500

501

502

503

504

505

506

507

508

509

510

511

512

513

514

515

516

517

518

519

520

521

522

523

524

525

526

527

528

529

Pellegrini T, Lopes Ferreira R. 2012. Management in a neotropical show cave: planning for invertebrates conservation. International Journal of Speleology 41:359-366. DOI: 10.5038/1827-806X.41.2.19.

Pellegrini T, Sales LP, Aguiar P, Lopes Ferreira R. 2016. Linking spatial scale dependence of land-use descriptors and invertebrate cave community composition. Subterranean Biology 18:17-38. DOI: 10.3897/subtbiol.18.8335.

Pipan T, Culver D. C. 2013. Subterranean Ecosystems. In: Levin SA ed. Encyclopedia of Biodiversity. Waltham, MA: Academic Press., 44-62. DOI: 10.1016/B0-12-2268652/00262-5.

Poveromo JJ. 1999. Iron Ores. In: The Making, Shaping, and Treating of Steel: Ironmaking volume. Pittsburg, PA: The AISE Steel Foundation, 547-550.

R CT. 2020. R: A language and environment for statistical computing.

Rabelo LM, Souza-Silva M, Ferreira RL. 2020. Epigean and hypogean drivers of Neotropical subterranean communities. Journal of Biogeography:jbi.14031. DOI: 10.1111/jbi.14031.

Di Russo C, Carchini G, Rampini M, Lucarelli M, Sbordoni V. 1997. Long term stability of a terrestrial cave community. International Journal of Speleology 26:7.

Salvidio S, Costa A, Oneto F, Pastorino MV. 2019. Variability of A Subterranean Prey-Predator Community in Space and Time. Diversity 12:17. DOI: 10.3390/d12010017.

Silva MS, Martins RP, Ferreira RL. 2011. Cave lithology determining the structure of the invertebrate communities in the Brazilian Atlantic Rain Forest. Biodiversity and Conservation 20:1713-1729.

Simões MH, Souza-Silva M, Ferreira RL. 2015. Cave physical attributes influencing the structure of terrestrial invertebrate communities in Neotropics. Subterranean Biology 16:103-121.

Sonter LJ, Ali SH, Watson JEM. 2018. Mining and biodiversity: key issues and research needs in conservation science. Proceedings of the Royal Society B: Biological Sciences 285:20181926. DOI: 10.1098/rspb.2018.1926.

Souza-Filho PWM, Giannini TC, Jaffé R, Giulietti AM, Santos DC, Nascimento Jr. WR, Guimarães JTF, Costa MF, Imperatriz- Fonseca VL, Siqueira JO. 2019. Mapping and quantification of ferruginous outcrop savannas in the Brazilian Amazon: A challenge for biodiversity conservation. PLOS ONE 14:e0211095.

Souza-Silva M, Iniesta LFM, Ferreira RL. 2020. Cave lithology effect on subterranean biodiversity: A case study in quartzite and granitoid caves. Acta Oecologica 108:103645. DOI: $10.1016 /$ j.actao.2020.103645.

Souza CM, Z. Shimbo J, Rosa MR, Parente LL, A. Alencar A, Rudorff BFT, Hasenack H, Matsumoto M, G. Ferreira L, Souza-Filho PWM, de Oliveira SW, Rocha WF, Fonseca A V., 
530

531

532

533

534

535

536

537

538

539

540

541

542

543

544

545

546

547

548

549

550

551

552

553

554

555

556

557

558

559

560

561

562

563

564

565

Marques CB, Diniz CG, Costa D, Monteiro D, Rosa ER, Vélez-Martin E, Weber EJ, Lenti FEB, Paternost FF, Pareyn FGC, Siqueira J V., Viera JL, Neto LCF, Saraiva MM, Sales MH, Salgado MPG, Vasconcelos R, Galano S, Mesquita V V., Azevedo T. 2020. Reconstructing Three Decades of Land Use and Land Cover Changes in Brazilian Biomes with Landsat Archive and Earth Engine. Remote Sensing 12:2735. DOI: 10.3390/rs12172735.

Di Stefano J. 2001. Power analysis and sustainable forest management. Forest Ecology and Management 154:141-153. DOI: 10.1016/S0378-1127(00)00627-7.

Tobin B, Hutchins B, Schwartz B. 2013. Spatial and temporal changes in invertebrate assemblage structure from the entrance to deep-cave zone of a temperate marble cave. International Journal of Speleology 42:203-214. DOI: 10.5038/1827-806X.42.3.4.

Trajano E. 2013. Variações anuais e infra-anuais em ecossistemas subterrâneos: implicações para estudos ambientais e preservação de cavernas. Revista da Biologia 10:1-7. DOI: 10.7594/revbio.10.02.01.

Trajano E, Bichuette ME. 2010. Relevância de cavernas: porque estudos ambientais espeleobiológicos não funcionam. Espeleo-Tema 21:105-112.

Trevelin LC, Gastauer M, Prous X, Nicácio G, Zampaulo R, Brandi I, Oliveira G, Siqueira JO, Jaffé R. 2019. Biodiversity surrogates in Amazonian iron cave ecosystems. Ecological Indicators 101:813-820. DOI: 10.1016/j.ecolind.2019.01.086.

Vale SA. 2015. Plano de Básico Ambiental Consolidado Complexo Minerador Ferro Carajás Parauapebas, PA.

Vale SA. 2017. Plano de Básico Ambiental do Projeto S11D -, Canaã dos Carajás, PA.

Wang IJ. 2020. Topographic path analysis for modelling dispersal and functional connectivity: Calculating topographic distances using the $<$ scp $>$ topoDistance $\mathrm{r}</$ scp $>$ package. Methods in Ecology and Evolution 11:265-272. DOI: 10.1111/2041-210X.13317.

Wang Y, Naumann U, Wright ST, Warton DI. 2012. mvabund - an R package for model-based analysis of multivariate abundance data. Methods in Ecology and Evolution 3:471-474. DOI: 10.1111/j.2041-210X.2012.00190.x.

Wynne J, Howarth F, Sommer S, Dickson B. 2019. Fifty years of cave arthropod sampling: techniques and best practices. International Journal of Speleology 48:33-48. DOI: 10.5038/1827-806X.48.1.2231.

Wynne JJ, Sommer S, Howarth FG, Dickson BG, Voyles KD. 2018. Capturing arthropod diversity in complex cave systems. Diversity and Distributions 24:1478-1491. DOI: 10.1111/ddi.12772.

Zappi DC, Moro MF, Walker B, Meagher T, Viana PL, Mota NFO, Watanabe MTC, Nic Lughadha E. 2019. Plotting a future for Amazonian canga vegetation in a campo rupestre context. PLOS ONE 14:e0219753. DOI: 10.1371/journal.pone.0219753. 


\section{Table $\mathbf{1}$ (on next page)}

List of surveyed taxa and their ecological classification. 
1 Table 1: List of surveyed taxa and their ecological classification.

2

\begin{tabular}{|c|c|c|c|c|}
\hline Class & Order & Family & Species & $\begin{array}{l}\text { Ecological } \\
\text { Classification }\end{array}$ \\
\hline Malacostraca & Isopoda & Scleropactidae & $\begin{array}{l}\text { Circoniscus carajasensis } \\
\text { Campos-Filho \& Araujo, } 2011\end{array}$ & Troglobiont \\
\hline \multirow[t]{2}{*}{ Amphibia } & Anura & Craugastoridae & $\begin{array}{l}\text { Pristimantis cf. fenestratus } \\
\text { (Steindachner, 1864) }\end{array}$ & Trogloxene \\
\hline & & Leptodactylidae & $\begin{array}{l}\text { Leptodactylus pentadactylus } \\
\text { (Laurenti, 1768) }\end{array}$ & Accidental \\
\hline \multirow[t]{14}{*}{ Arachnida } & Amblypygi & Phrynidae & $\begin{array}{l}\text { Heterophrynus longicornis } \\
\text { Butler, } 1873\end{array}$ & Troglophile \\
\hline & & Charinidae & $\begin{array}{l}\text { Charinus ferreus Giupponi \& } \\
\text { Miranda, } 2016\end{array}$ & Troglobiont \\
\hline & Araneae & Araneidae & Alpaida sp.1 & Troglophile \\
\hline & & Pholcidae & Mesabolivar spp. & Troglophile \\
\hline & & Prodidomidae & Prodidomidae sp. & Troglobiont \\
\hline & & Salticidade & Astieae sp.1 & Troglophile \\
\hline & & Scytodidae & $\begin{array}{l}\text { Scytodes eleonorae Rheims \& } \\
\text { Brescovit, } 2001\end{array}$ & Troglophile \\
\hline & & Theraphosidae & Theraphosidae & Troglophile \\
\hline & & $\begin{array}{l}\text { Theridiosomatida } \\
\text { de }\end{array}$ & Plato spp. & Troglophile \\
\hline & Opiliones & Cosmetidae & $\begin{array}{l}\text { Roquettea singularis Mello- } \\
\text { Leitão, } 1931\end{array}$ & Troglophile \\
\hline & & & Roquettea sp. & Troglophile \\
\hline & & Escadabiidae & Escadabiidae sp.1 & Troglobiont \\
\hline & & & Escadabiidae sp.2 & Troglobiont \\
\hline & & Gagrellinae & Prionostemma sp. & Troglophile \\
\hline
\end{tabular}




\begin{tabular}{|c|c|c|c|c|}
\hline & & Stygnidae & Protimesius sp. & Troglophile \\
\hline & & & Stygnidae sp.1 & Troglophile \\
\hline Chilopoda & Scutigeromorpha & Pselliodidae & $\begin{array}{l}\text { Sphendononema guildingii } \\
\text { (Newport, 1845) }\end{array}$ & Troglophile \\
\hline \multirow[t]{5}{*}{ Diplopoda } & Glomeridesmida & Glomeridesmidae & $\begin{array}{l}\text { Glomeridesmus cf. spelaeus } \\
\text { Iniesta, Ferreira \& Wesener, } \\
2012\end{array}$ & Troglobiont \\
\hline & Polydesmida & Chelodesmidae & Chelodesmidae sp. & Troglophile \\
\hline & & Pyrgodesmidae & Pyrgodesmidae sp.1 & Troglobiont \\
\hline & Spirostreptida & - & Spirostreptida sp. & Troglophile \\
\hline & & $\begin{array}{l}\text { Pseudonannolenid } \\
\text { ae }\end{array}$ & $\begin{array}{l}\text { Pseudonannolene cf. spelaea } \\
\text { Iniesta \& Ferreira, } 2013\end{array}$ & Troglobiont \\
\hline \multirow[t]{6}{*}{ Insecta } & Coleoptera & Dytiscidae & Dytiscidae sp.1 & Stygobiont \\
\hline & Hemiptera & Cydnidae & Cydninae sp.1 & Troglophile \\
\hline & & Reduviidae & Emesinae sp. & Troglophile \\
\hline & Lepidoptera & Erebidae & Latebraria sp. & Trogloxene \\
\hline & Orthoptera & Phalangopsidae & $\begin{array}{l}\text { Phalangopsis ferratilis Junta, } \\
\text { Castro-Souza \& Ferreira, } 2020\end{array}$ & Troglophile \\
\hline & & & Uvaroviella sp. & Troglophile \\
\hline Mammalia & Rodentia & Cricetidae & Rhipidomys sp. & Undefined \\
\hline Reptilia & Squamata & Phyllodactylidae & $\begin{array}{l}\text { Thecadactylus rapicauda } \\
\text { (Houttuyn, 1782) }\end{array}$ & Undefined \\
\hline
\end{tabular}




\section{Table 2 (on next page)}

Summary of partial Redundancy Analyses (RDA).

The table shows F-statistics and $p$-values from permutation tests (adjusted $r^{2}=0.13$ ). 
1 Table 2: Summary of partial Redundancy Analyses (RDA). The table shows F-statistics and $p$ 2 values from permutation tests (adjusted $r^{2}=0.13$ ).

3

\begin{tabular}{|l|c|c|c|l|}
\hline Variable & Df & Variance & F & \multicolumn{1}{|c|}{$\boldsymbol{P r}(>\boldsymbol{F})$} \\
\hline Season nested in year & 1 & 0.0018 & 4.408 & $0.001^{* * *}$ \\
\hline Canga cover & 1 & 0.0005 & 1.164 & 0.285 \\
\hline Forest cover & 1 & 0.0008 & 2.093 & $0.055^{*}$ \\
\hline Mining cover & 1 & 0.0010 & 2.378 & $0.034^{*}$ \\
\hline Distance to mine & 1 & 0.0027 & 6.766 & $0.001^{* * *}$ \\
\hline Area & 1 & 0.0197 & 48.696 & $0.001^{* * *}$ \\
\hline Temperature & 1 & 0.0054 & 13.408 & $0.001^{* * *}$ \\
\hline Dev Rainfall & 1 & 0.0002 & 0.604 & 0.746 \\
\hline Residual & 671 & 0.2710 & & \\
\hline
\end{tabular}

4

5 


\section{Table 3 (on next page)}

Taxa displaying significant responses to disturbance metrics, considering overall abundance and temporal abundance trends.

Taxa showing consistent responses (highlighted in bold) are suggested as short-term

disturbance indicators. The best sampling season (according to Fig. 3), is indicated for each taxa. 
1 Table 3: Taxa displaying significant responses to disturbance metrics, considering overall

2 abundance and temporal abundance trends. Taxa showing consistent responses (highlighted in

3 bold) are suggested as short-term disturbance indicators. The best sampling season (according to

4 Fig. 3), is indicated for each taxa.

5

\begin{tabular}{|c|c|c|c|c|c|}
\hline \multirow{2}{*}{ Taxon } & \multicolumn{2}{|c|}{ Abundance } & \multicolumn{2}{|c|}{ Temporal abundance trend } & \multirow{2}{*}{ Sampling } \\
\hline & \multicolumn{4}{|c|}{ Distance to mine Mining cover Distance to mine Mining cove } & \\
\hline Charinus ferreus* & - & Negative & Positive & Negative & Dry \\
\hline Theraphosidae & Negative & Positive & - & Positive & Dry \\
\hline Uvaroviella sp. & Negative & - & Positive & Negative & Both \\
\hline Rhipidomys sp. & - & - & Positive & - & Dry \\
\hline Roquettea sp. & - & - & - & Positive & Rain \\
\hline Pyrgodesmidae sp.1* & - & Negative & - & - & Rain \\
\hline Spirostreptida sp.1 & Positive & - & - & - & Rain \\
\hline Prodidomidae sp.* & Positive & Negative & & & Dry \\
\hline Escadabiidae sp.1* & Negative & Negative & - & - & Rain \\
\hline Escadabiidae sp.2* & Positive & - & - & - & Rain \\
\hline $\begin{array}{l}\text { Leptodactylus } \\
\text { pentadactylus }\end{array}$ & Negative & - & - & - & Both \\
\hline $\begin{array}{l}\text { Pristimantis } \\
\text { fenestratus }\end{array}$ & Negative & Positive & - & - & Dry \\
\hline $\begin{array}{l}\text { Thecadactylus } \\
\text { rapicauda }\end{array}$ & - & Negative & - & - & Dry \\
\hline Plato spp. & Negative & - & - & - & Dry \\
\hline $\begin{array}{l}\text { Sphendononema } \\
\text { guildingii }\end{array}$ & - & Positive & - & - & Dry \\
\hline Astieae sp.1 & Negative & - & - & - & Dry \\
\hline Protimesius sp. & Negative & - & - & - & Rain \\
\hline Prionostemma sp. & Negative & Positive & - & - & Dry \\
\hline Stygnidae sp1 & - & Positive & - & - & Dry \\
\hline Phalangopsis sp.1 & - & Positive & - & - & Dry \\
\hline
\end{tabular}

6 * Troglobitic species 


\section{Figure 1}

Location of the study region (upper left corner) and a detail of the study area showing the spatial distribution of the caves included in our analyses ( $N=95)$, colored by the number of surveys performed in each.

While the hillshade layer was constructed using a digital elevation model (SRTM, 1 arcsecond) from USGS Earth Explorer, the land use classification shapefile was obtained from Souza-Filho et al. (2019). Coordinates are shown in decimal degrees.

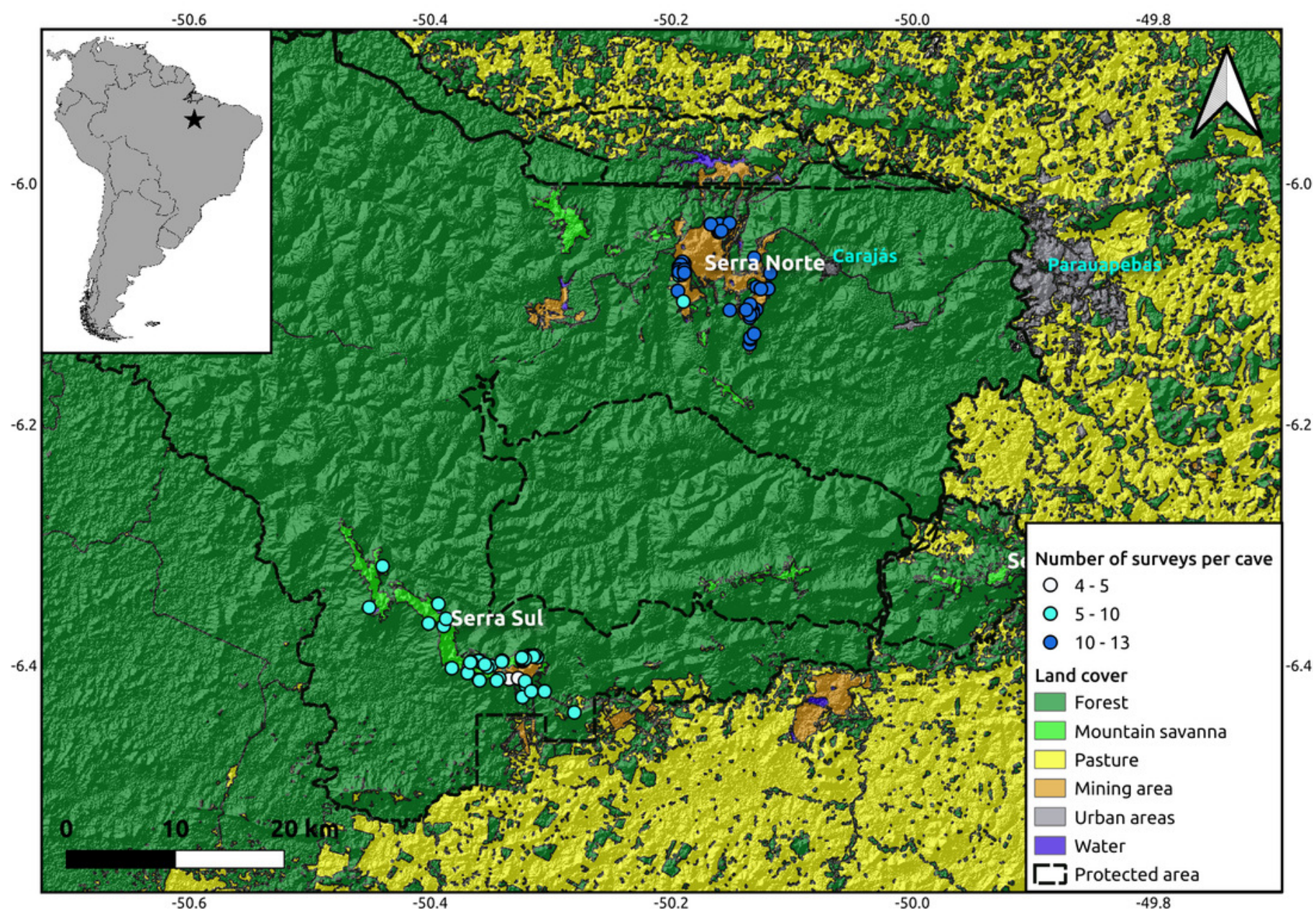


Figure 2

Adjusted $p$-values for the interaction between sampling date and season across 16 taxa and 50 caves.

The Benjamini \& Hochberg approach was used to adjust $p$-values and the red horizontal line shows the threshold value of 0.05 (values above this line represent cases where the interaction effect was not significant). 


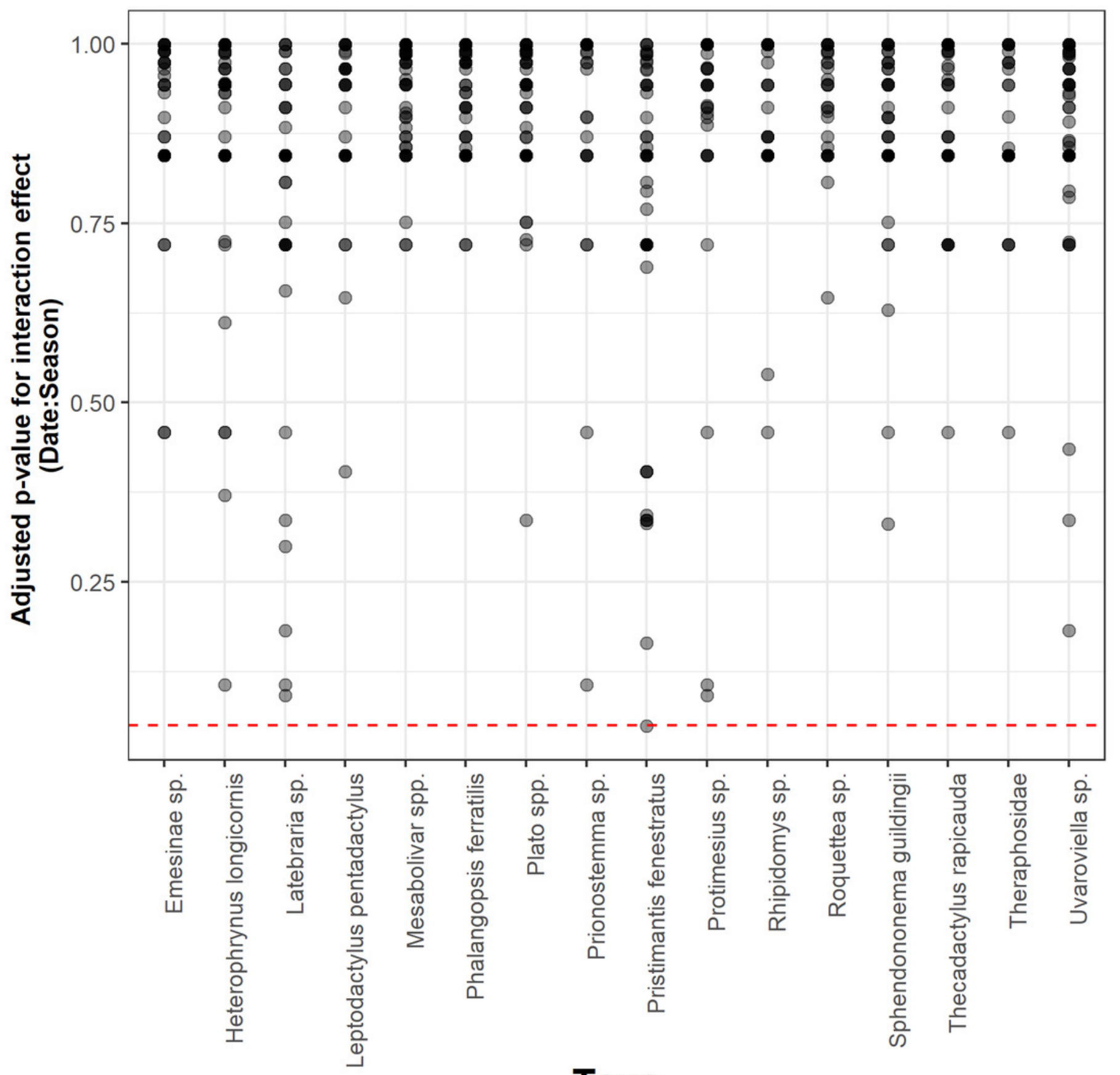

Taxa 
Figure 3

Root mean squared error (rmse) for model coefficients from full models and those of subset models containing reduced numbers of samples.

Lower values of rmse indicate more similar model coefficients (and a more reliable estimation of temporal abundance trends). For each data subset containing a given number of observations (surveys) we performed ten random samplings without replacement, to ensure the sampling of different sampling dates.
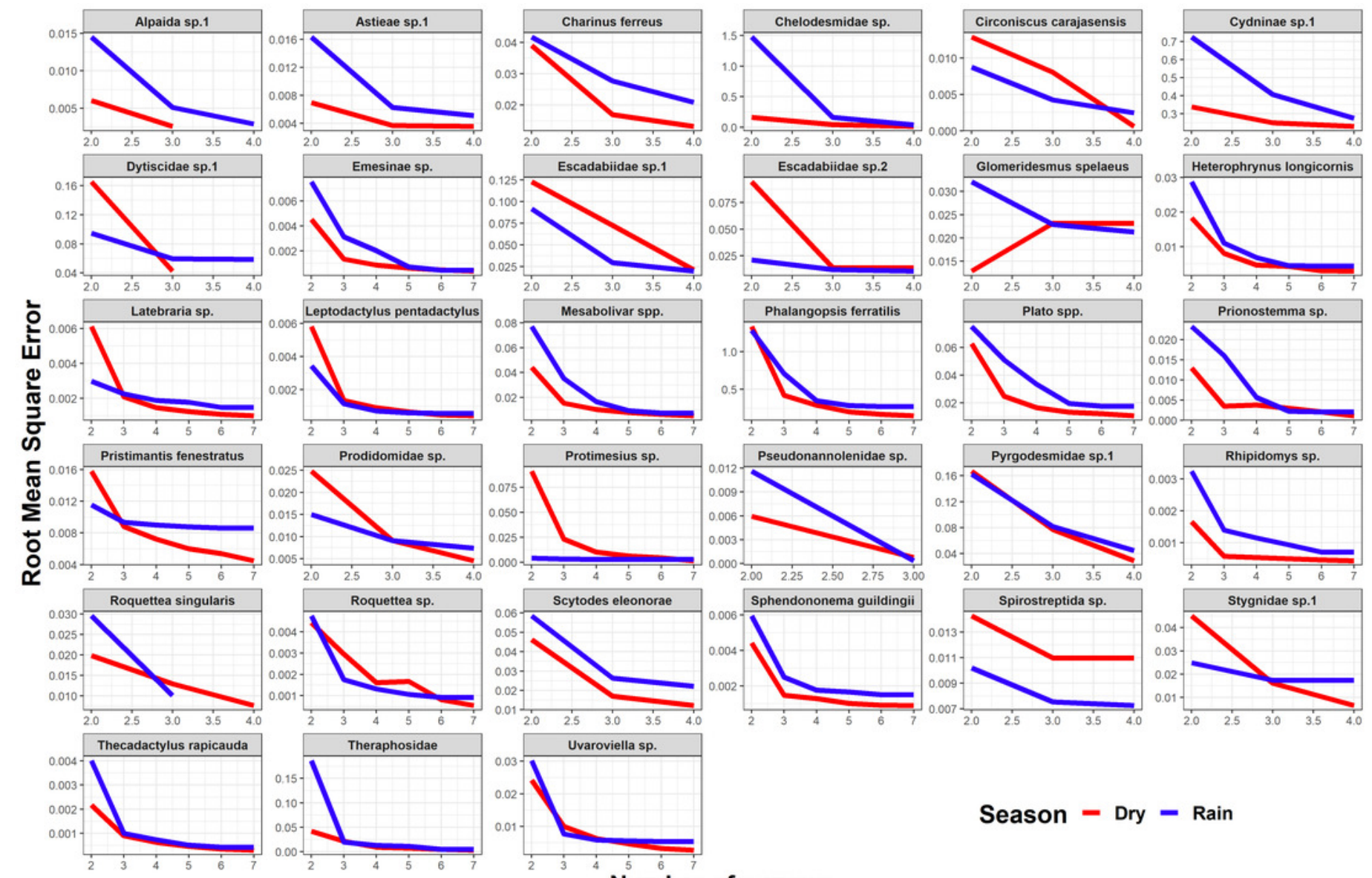

Season - Dry - Rain

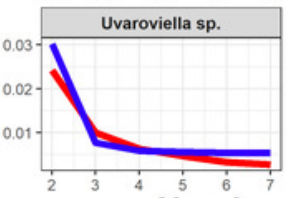

Number of surveys 
Figure 4

Model coefficients and 95\% confidence intervals for species showing significant associations between overall abundance and two disturbance metrics.
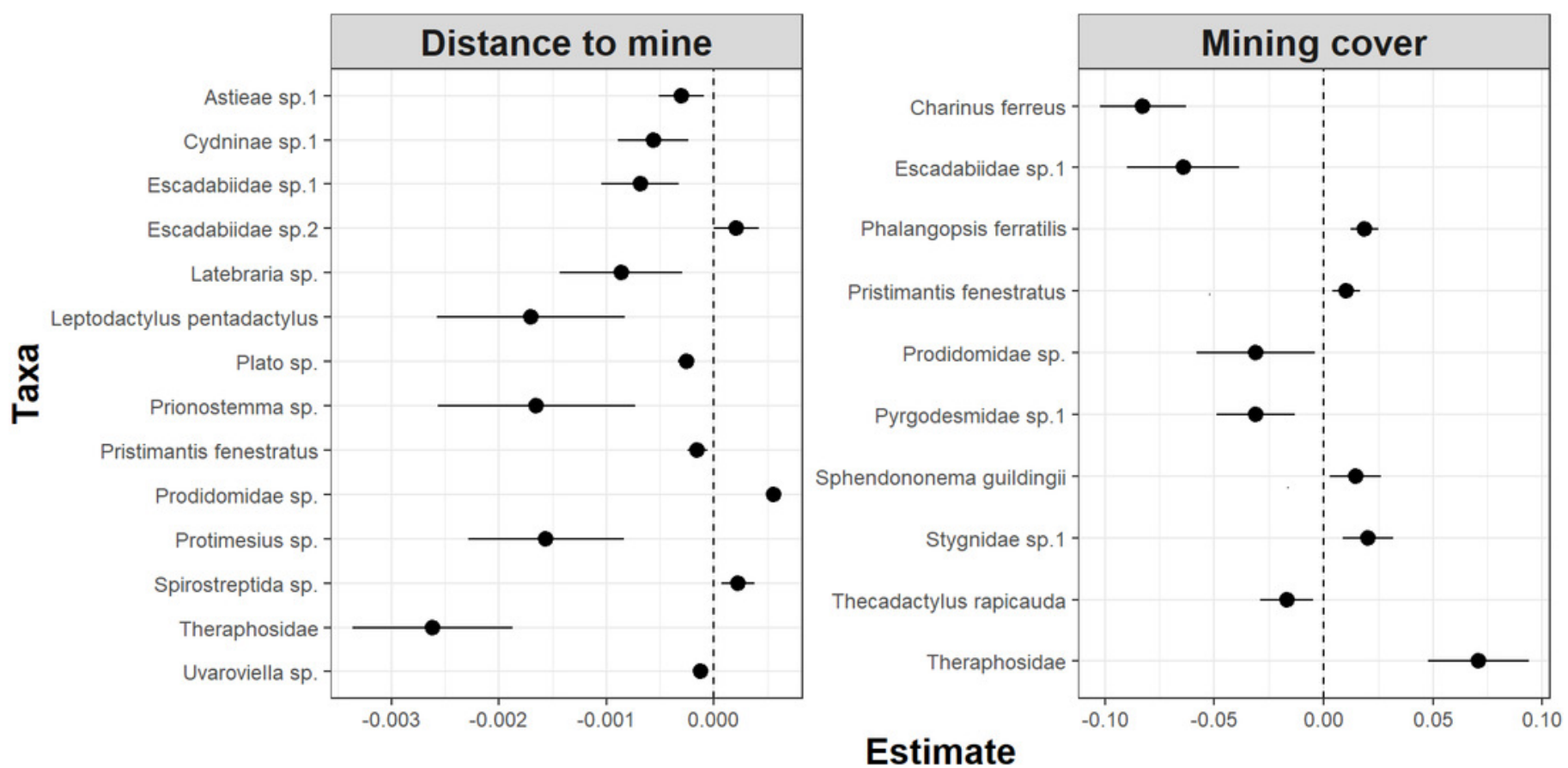
Figure 5

Model coefficients and 95\% confidence intervals for species showing significant associations between temporal abundance trends and two disturbance metrics.

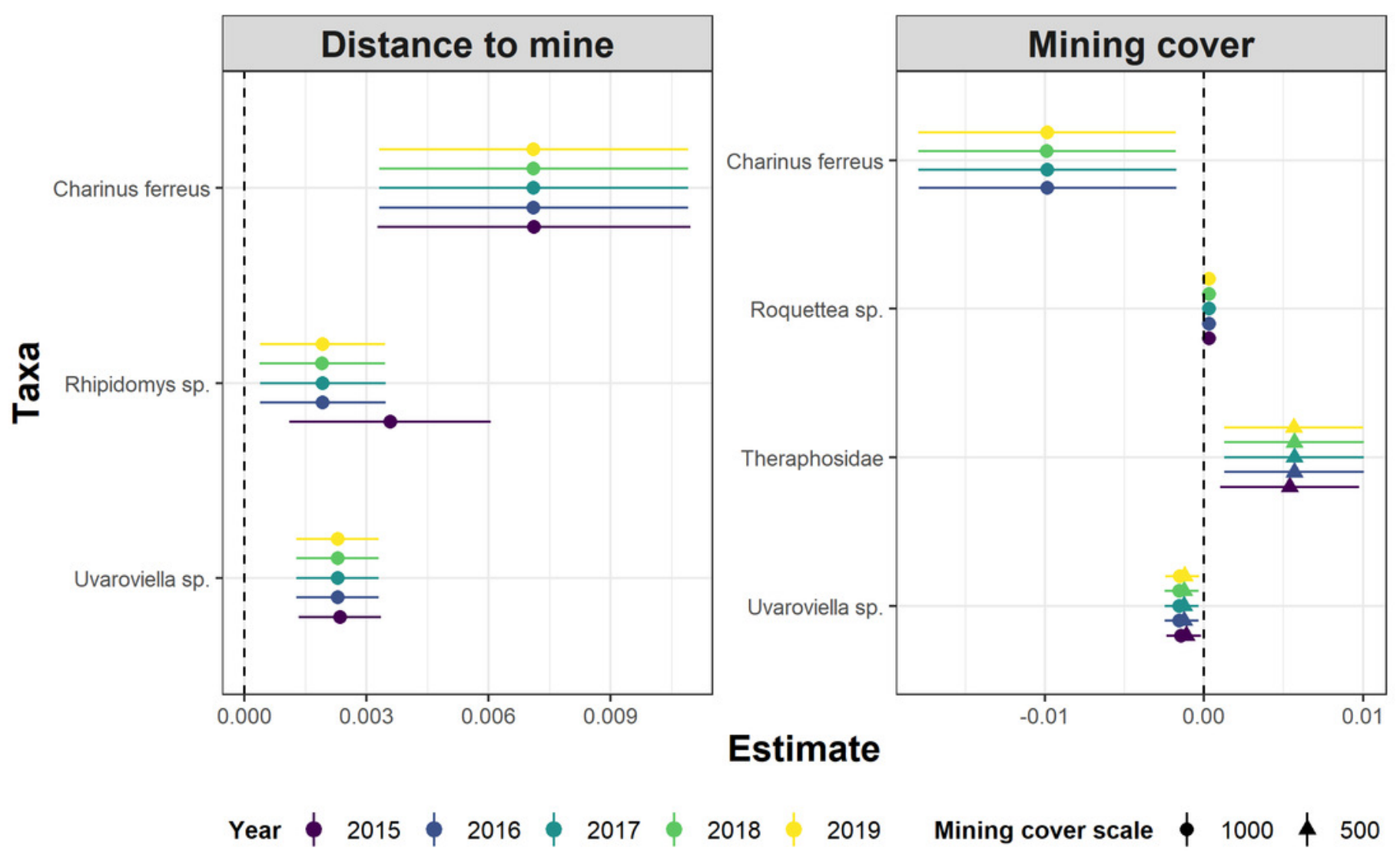

